\title{
Correction to: A discrete element framework for the numerical analysis of particle bed-based additive manufacturing processes
}

\author{
Bram J. A. Dorussen ${ }^{1}$ (D ) Marc G. D. Geers ${ }^{1}$. Joris J. C. Remmers ${ }^{1}$
}

Published online: 4 March 2022

(c) The Author(s) 2022

\section{Correction to: Engineering with Computers https://doi.org/10.1007/s00366-021-01590-6}

In the original version of the article, Figs. 1 and 5 were depicted too small and the captions of the subfigures of Figs. 2a, b, 3a, b, 11a, b, 18a-d and 19a, b were not properly formatted.

The original article has been corrected.

Open Access This article is licensed under a Creative Commons Attribution 4.0 International License, which permits use, sharing, adaptation, distribution and reproduction in any medium or format, as long as you give appropriate credit to the original author(s) and the source, provide a link to the Creative Commons licence, and indicate if changes were made. The images or other third party material in this article are included in the article's Creative Commons licence, unless indicated otherwise in a credit line to the material. If material is not included in the article's Creative Commons licence and your intended use is not permitted by statutory regulation or exceeds the permitted use, you will need to obtain permission directly from the copyright holder. To view a copy of this licence, visit http://creativecommons.org/licenses/by/4.0/.

Publisher's Note Springer Nature remains neutral with regard to jurisdictional claims in published maps and institutional affiliations.

Bram J. A. Dorussen

b.j.a.dorussen@tue.nl

Marc G. D. Geers

m.g.d.geers@tue.nl

Joris J. C. Remmers

j.j.c.remmers@tue.nl

1 Mechanical Engineering, Mechanics of Materials, Eindhoven University of Technology, PO Box 513, $5600 \mathrm{MB}$ Eindhoven, Noord-Brabant, The Netherlands 